\title{
ANALISIS SELF ASSESSMENT SYSTEM TERHADAP TINGKAT KEPATUHAN WAJIB PAJAK \\ (Studi kasus Pada KPP Pratama Natar)
}

\author{
Hengky Achmad Subing \\ Asih Pratiwi \\ Haninun
}

\begin{abstract}
Pajak merupakan tumpuan sumber penerimaan Negara, dan berdasarkan jenisnya Pajak Penghasilan $(\mathrm{PPh})$ telah memberikan kontribusi terbesar. PPh sebagai penerimaan negara dipungut dengan menggunakan sistem self assessment yang memberikan wewenang bagi wajib pajak untuk menghitung, memperhitungkan, membayar dan melaporkan sendiri pajak terutangnya. Adapun objek penelitian ini dilakukan pada KPP Pratama Natar-Lampung Selatan. Dalam penelitian ini penulis menggunakan pengumpulan data dengan menggunakan sumber data yang berasal dari data primer dan data sekunder sedangkan metode pengumpulan data yang digunakan yaitu dengan penelitian kepustakaan, dan penelitian lapangan yang terdiri dokumentasi dan quisioner serta metode penelitian adalah populasi dan sampel dan analisis yang digunakan adalah analisis deskriptif.

Hasil penelitian dengan menguji Tanggapan Self Assessment System menurut wajib pajak telah menunjukkan bahwa variabel bebas dalam penelitian ini memiliki pengaruh yang cukup baik terhadap peningkatan penerimaan $\mathrm{PPh}$ yang diikuti dengan peningkatan jumlah wajib pajak, karena penerapan sistem ini menuntut aktif wajib pajak untuk menghitung, memperhitungkan, membayar, dan melaporkan pajak yang terutang sehingga wajib pajak berperan penting dalam pengaruh Self Assessment System terhadap tingkat kepatuhan wajib pajak pada KPP Natar.
\end{abstract}

\section{LATAR BELAKANG}

Perencanaan pajak juga dapat berkonotasi positif yaitu sebagai perencanaan pemenuhan kewajiban perpajakan secara lengkap, benar, dan tepat waktu sehingga dapat menghindari pemborosan sumber daya secara optimal. Dalam pelaksanaannya terdapat perbedaan kepentingan antara pemerintah dan Wajib Pajak. Wajib Pajak berusaha untuk membayar pajak sekecil mungkin, karena dengan membayar pajak berarti mengurangi kemampuan Wajib Pajak.

Dilain pihak pemerintah memerlukan dana untuk membiayai pengeluaran dalam rangka penyelenggaraan pemerintahan, yang sebagian besar berasal dari penerimaan pajak. Adanya perbedaan kepentingan tersebut menyebabkan Wajib Pajak cenderung untuk mengurangi jumlah pembayaran pajak baik secara legal maupun ilegal. Karena untuk menjalankan pemerintahan dan pembangunan pemerintah membutuhkan dana yang tidak sedikit. Dana tersebut dari berbagai sumber penghasilan kekayaan alam, hasil usaha BUMN, barang-barang yang dikuasai pemerintah, denda-denda, atau warisan yang diberikan kepada negara, hibah, wafat, dan iuran masyarakat kepada Negara berdasarkan undang-undang 
(dipaksakan) dengan tidak mendapat jasa timbal (kontraprestasi yang dapat ditunjuk dan yang digunakan untuk membayar pengeluaran).

Sistem self assessment memberikan kepercayaan penuh kepada Wajib Pajak, maka selayaknya diimbangi dengan adanya pengawasan yang diberikan tidak disalahgunakan. Dalam prinsip self assesment system, penentuan besarnya pajak terutang dipercayakan kepada Wajib Pajak sendiri melalui Surat Pemberitahuan yang disampaikan. Perubahan sistem pemungutan pajak dari official assessment menjadi self assessment, merupakan salah satu upaya pemerintah untuk meningkatkan kemandirian dalam pembiayaan pembangunan dari penerimaan dalam negeri yang berasal dari pajak, karena penerimaan dari migas tidak dapat diandalkan lagi, sementara sumber dana dalam negeri hanya sebagai pelengkap.

\section{Telaah Literatur dan Pengembangan Hipotensi}

\section{Pengertian Pajak}

Pajak adalah prestasi yang dipaksakan sepihak oleh dan terutang kepada pengusaha (menurut norma-norma yang ditetapkannya secara umum), tanpa adanya kontraprestasi, dan semata-mata digunakan untuk menutupi pengeluaran-pengeluaran umum. Karena pajak merupakan prestasi kepada pemerintah yang terutang melalui norma-norma umum yang dapat dipaksakannya, tanpa adanya kontraprestasi yang dapat ditunjukan dalam hal individual, dimaksudkan untuk membiayai pengeluaran pemerintah.

Pajak juga didefinisikan sebagai iuran masyarakat kepada Negara (yang dapat dipaksakan) yang terutang oleh wajib pajak membayarnya menurut peraturan-peraturan umum (undang-undang) dengan tidak mendapat prestasi kembali yang langsung dapat ditunjuk dan yang gunanya adalah untuk membiayai pengeluaran-pengeluaran umum berhubungan tugas Negara untuk menyelenggarakan pemerintahan. Pemungutan pajak di suatu Negara dianggap sukses apabila terdapat enam kondisi pendukung, yaitu:

1. Sebagian besar aktifitas ekonomi dilaksanakan dalam transaksi uang.

2. Tingkat iliterasi (buta huruf) masyarakat rendah.

3. Adanya praktek pembukuan (administrasi) yang sehat dan dapat dipercaya (reliable).

4. Tingkat kepatuhan dan disiplin yang tinggi.

5. Tersedianya jaringan dan akses terhadap informasi serta komunikasi yang efektif dengan sedikit (menghilangkan) kerahasiaan (untuk tujuan perpajakan).

6. Rendahnya tingkat sektor (ekonomi) informal (underground, black market economy).

\section{Fungsi Pajak}

Terdapat dua fungsi pajak, yaitu fungsi budgetair (sumber keuangan negara) dan fungsi regulerend (mengatur) yaitu:

1. Fungsi Budgetair (Sumber Keuangan Negara)

Pajak mempunyai fungi budgetair artinya pajak merupakan salah satu sumber penerimaan pemerintah untuk membiayai pengeluaran baik rutin maupun pembangunan.

2. Fungsi Regulerend (Mengatur)

Pajak mempunyai fungsi regulerend artinya pajak sebagai alat untuk mengatur atau melaksanakan kebijakan pemerintah dalam bidang sosial dan ekonomi, dan mencapai tujuan-tujuan tertentu di luar bidang keuangan.

\section{Jenis Pajak}

Di Indonesia pajak dikelompokkan menurut beberapa kategori, yaitu menurut golongannya, menurut sifatnya, dan menurut lembaga pemungutannya. 


\section{A. Menurut Golongannya}

1. Pajak Langsung, adalah pajak yang harus dipikul atau ditanggung sendiri oleh Wajib Pajak dan tidak dilimpahkan atau dibebankan kepada orang lain atau pihak lain.

2. Pajak Tidak Langsung, adalah pajak yang pada akhirnya dapat dibebankan atau dilimpahkan kepada orang lain atau pihak ketiga.

\section{B. Menurut Sifatnya}

1. Pajak Subjektif, adalah pajak yang pengenaannya memperhatikan pada keadaan pribadi Wajib Pajak atau pengenaan pajak yang memperhatikan keadaan subjeknya.

2. Pajak Objektif, adalah pajak yang pengenaanya memperhatikan pada objeknya baik pada berupa benda, keadaan, perbuatan, atau peristiwa yang mengakibatkan timbulnya kewajiban membayar pajak, tanpa memperhatikan keadaan subjek pajak maupun tempat tinggal.

\section{Menurut Lembaga Pemungutannya}

1. Pajak Negara (Pajak Pusat), adalah pajak yang dipungut oleh Pemerintah Pusat dan digunakan untuk membiayai rumah tangga negara pada umumnya.

2. Pajak Daerah, yaitu pajak yang dipungut oleh Pemerintah Daerah baik Daerah Tingkat I maupun Daerah Tingkat II dan digunakan untuk membiayai rumah tangga daerah masing-masing.

\section{Tata Cara Pemungutan Pajak}

\section{Asas-Asas Pemungutan Pajak}

Terdapat empat asas-asas pemungutan pajak yaitu:.

1) Equality

Pemungutan pajak harus bersifat adil dan merata, yaitu pajak dikenakan kepada orang pribadi yang harus sebanding dengan kemampuan membayar pajak atau ability to pay dan sesuai dengan manfaat yang diterima. Adil dimaksudkan bahwa setiap Wajib Pajak menyumbangkan uang untuk pengeluaran pemerintah sebanding dengan kepentingannya dan manfaat yang diminta.

2) Certainty

Penetapan pajak itu tidak ditentukan sewenang-wenang. Oleh karena itu, Wajib Pajak harus mengetahui secara jelas dan pasti besarnya pajak yang terutang, kapan harus bayar, serta batas waktu pembayaran.

3) Convenience

Kapan Wajib Pajak itu harus membayar pajak sebaiknya sesuai dengan saat-saat yang tidak menyulitkan Wajib Pajak. Sistem pemungutan ini disebut Pay as You Earn

4) Economy

Secara ekonomi bahwa biaya pemungutan dan biaya pemenuhan kewajiban pajak bagi Wajib Pajak diharapkan seminimum mungkin, demikian pula beban yang dipikul Wajib Pajak.

\section{Sistem Pemungutan Pajak}

Beberapa sistem pemungutan pajak, yaitu antara lain:

\section{Official Assessment System}

Suatu sistem pemungutan pajak yang memberi kewenangan aparatur perpajakan untuk menentukan sendiri jumlah pajak yang terutang setiap tahunnya sesuai dengan ketentuan undang-undang perpajakan yang berlaku.

\section{Self Assessment System}


Suatu sistem pemungutan pajak yang memberi wewenang Wajib Pajak untuk menentukan sendiri jumlah pajak yang terutang setiap tahunnya sesuai dengan ketentuan undang-undang perpajakan yang berlaku.

\section{With Holding System}

Suatu sistem pemungutan pajak yang memberi wewenang kepada pihak ketiga yang ditunjuk untuk menentukan besarnya pajak yang terutang oleh Wajib Pajak sesuai dengan ketentuan undang-undang perpajakan yang berlaku.

\section{Self Assessment System}

Sistem Self Assessment adalah suatu sistem yang memberikan kepercayaan dan tanggung jawab kepada Wajib Pajak untuk menghitung, memperhitungkan dan membayar sendiri jumlah pajak yang terutang sesuai dengan ketentuan perpajakan yang berlaku. Selain itu Wajib Pajak diwajibkan pula melaporkan secara teratur jumlah pajak yang terutang dan telah dibayar sebagaimana ditentukan dalam peraturan perpajakan. Pembayaran pajak selama tahun berjalan pada dasarnya merupakan angsuran pajak untuk meringankan beban Wajib Pajak pada akhir tahun pajak. Hakikat Self Assessment System adalah penetapan sendiri besarnya pajak yang terutang oleh Wajib Pajak

\section{Wajib Pajak}

Menurut Undang-Undang Nomor 28 Tahun 2007 tentang Perubahan Ketiga Atas Undang-Undang Nomor 6 Tahun 1983 tentang Ketentuan Umum Perpajakan, Wajib Pajak adalah orang pribadi atau badan, meliputi pembayar pajak, pemungut pajak dan pemungut pajak yang mempunyai hak dan kewajiban perpajakan sesuai dengan ketentuan peraturan perundang-undangan perpajakan.

Adapun pengertian Wajib Pajak Efektif adalah Wajib Pajak yang memenuhi kewajiban perpajakannya, berupa memenuhi kewajiban menyampaikan Surat Pemberitahuan (SPT) Masa dan atau Tahunan sebagaimana mestinya. Sedangkan Wajib Pajak Non Efektif adalah Wajib Pajak yang tidak memenuhi kewajiban perpajakannya. Berdasarkan Surat Edaran SE-01/PJ.9/20 tentang Pengawasan Penyampaian SPT Tahunan disebutkan bahwa Jumlah Wajib Pajak efektif adalah selisih antara jumlah Wajib Pajak terdaftar dengan jumlah Wajib Pajak non efektif.

\section{Kepatuhan Wajib Pajak}

Kepatuhan pajak dapat didefinisikan sebagai suatu keadaan Wajib Pajak memenuhi semua kewajiban perpajakan dan melaksanakan hak perpajakannya. Kepatuhan juga perilaku yang taat hukum. Secara konsep, kepatuhan diartikan dengan adanya usaha dalam mematuhi peraturan hukum oleh seseorang atau organisasi. Dalam sistem self assessment, administrasi perpajakan berperan aktif melaksanakan tugas-tugas pembinaan, pengawasan dan penerapan sanksi terhadap penundaan pemenuhan kewajiban perpajakan berdasarkan ketentuan yang digariskan dalam peraturan perpajakan. Fungsi pengawasan memegang peranan sangat penting dalam sistem self assessment, karena tanpa pengawasan dalam kondisi tingkat kepatuhan Wajib Pajak masih rendah, mengakibatkan sistem tersebut tidak akan berjalan dengan baik, sehingga Wajib Pajak pun akan melaksanakan kewajiban pajaknya dengan tidak benar dan pada akhirnya penerimaan dari sektor pajak tidak akan tercapai.

\section{1) Indoctrination}

Sebab pertama warga masyarakat mematuhi kaidah-kaidah adalah karena dia didoktrinir untuk berbuat demikian. Sejak kecil manusia telah dididik agar mematuhi kaidah-kaidah 
yang berlaku dalam masyarakat sebagaimana halnya dengan unsur-unsur kebudayaan lainnya.

2) Habituation

Oleh karena sejak kecil mengalami proses sosialisasi, maka lama kelamaan menjadi suatu kebiasaan untuk mematuhi kaidah-kaidah yang berlaku.

3) Utility

Pada dasarnya manusia mempunyai kecenderungan untuk hidup pantas dan teratur, akan tetapi apa yang pantas dan teratur untuk seseorang, belum tentu pantas dan teratur bagi orang lain. Karena itu diperlukan patokan tentang kepantasan dan keteraturan tersebut, patokan tadi merupakan pedoman atau takaran tentang tingkah laku dan dinamakan kaedah. Dengan demikian, maka salah satu faktor yang menyebabkan orang taat pada kaidah adalah karena kegunaan dari pada kaidah tersebut.

4) Group Identification

Dari satu sebab mengapa seseorang patuh pada kaidah adalah karena kepatuhan tersebut merupakan salah satu sarana untuk mengadakan identifikasi dengan kelompok. Masalah kepatuhan yang merupakan suatu derajat secara kualitatif dapat dibedakan dalam tiga proses, yaitu:

1) Compliance

Compliance diartikan sebagai suatu kepatuhan yang didasarkan pada harapan akan suatu imbalan dan usaha untuk menghindarkan diri dari hukuman yang mungkin dijatuhkan. Kepatuhan ini sama sekali tidak didasarkan pada suatu keyakinan pada tujuan kaidah hukum yang bersangkutan dan lebih didasarkan pada pengendalian dari pemegang kekuasaan.

2) Identification

Identification terjadi apabila kepatuhan terhadap kaidah hukum ada bukan karena nilai intrinsiknya, akan tetapi agar keanggotaan kelompok tetap terjaga serta ada hubungan baik dengan mereka yang diberi wewenang untuk menerapkan kaidahkaidah hukum tersebut. Daya tarik untuk patuh adalah keuntungan yang diperoleh dari hubungan-hubungan tersebut, sehingga kepatuhan pun tergantung pada baik buruknya interaksi tadi.

3) Internalization

Pada Internalization seseorang mematuhi kaedah-kaedah hukum oleh karena secara intrinsik kepatuhan tadi mempunyai imbalan. Isi kaidah-kaidah tersebut adalah sesuai dengan nilai-nilainya sejak semula pengaruh terjadi, atau oleh karena dia merubah pola-pola yang semula dianutnya.

\section{Surat Pemberitahuan (SPT)}

Menurut UU No.28 tahun 2007 pasal 1 ayat 1, Surat Pemperitahuan adalah surat yang oleh Wajib Pajak digunakan untuk melaporkan penghitungan atau pembayaran pajak, objek pajak atau bukan objek pajak, atau harta dan kewajiban sesuai dengan ketentuan peraturan perundang-undangan. Surat Pemberitahuan (SPT) adalah surat yang digunakan oleh pemotong untuk melaporkan pemotongan, perhitungan, dan Penyetoran Pajak atas penghasilan orang pribadi sehubungan dengan pekerjaan atau jabatan, jasa, dan kegiatan. Surat Pemberitahuan (SPT) diterima adalah SPT yang dilaporkan setiap tahunnya dan diterima oleh KPP setempat. Adapun fungsi SPT bagi wajib pajak penghasilan yaitu:

1. Sarana melapor dan mempertanggungjawabkan penghitungan pajak sebenarnya terutang.

2. Melapor pembayaran atau pelunasan pajak yang telah dilaksanakan sendiri. 
3. Melaporkan pembayaran dari pemotong atau pemungut tentang pemotongan atau pemungutan pajak orang pribadi atau badan lain dari satu Masa Pajak sesuai dengan peraturan perundang-undangan perpajakan yang berlaku..

Penjelasan tersebut di uraikan pada kerangka pemikiran di bawah ini :

\begin{tabular}{|ll|}
\hline Self Assessment System (X) \\
\hline 1. & Menghitung \\
2. & Memperhitungkan \\
3. & Membayar \\
4. & Melaporkan \\
\hline
\end{tabular}

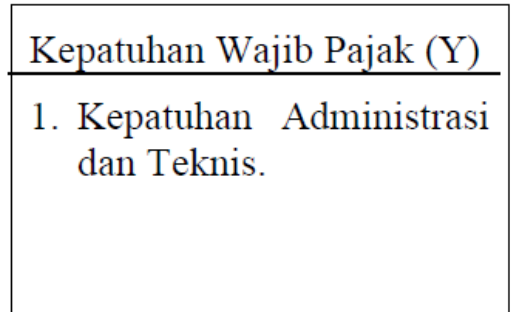

Gambar 2.1 Kerangka Pemikiran

Pada sistem ini, masyarakat Wajib Pajak diberikan kepercayaan dan tanggungjawab yang lebih besar untuk melaksanakan kewajibannya, yaitu :

1. Menghitung adalah Wajib Pajak menghitung besarnya pajak yang terhutang yang dilakukan setiap akhir bulan dan akhir tahun.

2. Memperhitungkan adalah Wajib Pajak mengurangi pajak yang terhutang dengan jumlah pajak yang telah dilunasi dalam tahun berjalan, selisih tersebut dapat berupa, kurang bayar maupun lebih bayar.

3. Membayar adalah Wajib Pajak membayarkan sendiri pajak yang telah dihitung ke kantor palayanan pajak.

4. Melaporkan adalah Wajib Pajak melaporkan sendiri mengenai perhitungan jumlah pajak yang terhutang maupun yang harus dibayarkan.

\section{METODOLOGI PENELITIAN}

\section{Objek Penelitian}

Kantor Pelayanan Pajak modern juga merupakan penggabungan dari Kantor Pelayanan Pajak konvensional dan Kantor Pemeriksaan dan Penyidikan Pajak. Kantor Pelayanan Pajak (KPP) modern terbagi dalam tiga jenis, yaitu Kantor Pelayanan Pajak Besar, Kantor Pelayanan Pajak Madya, dan Kantor Pelayanan Pajak Pratama. KPP Pratama yang dipimpin oleh seorang Kepala Kantor memiliki tugas melaksanakan penyuluhan, pelayanan dan pengawasan Wajib Pajak di bidang Pajak Penghasilan (PPh), Pajak Pertambahan Nilai (PPN), Pajak Penjualan atas Barang Mewah (PPnBM), dan Pajak Tidak Langsung Lainnya (PTLL).

\section{Pengumpulan Data}

Untuk memperoleh data primer maupun data sekunder, selain dengan cara menyebarkan daftar pertanyaan (Quisioner), penulis menggunakan metode lain untuk pengumpulan data sebagai data penunjang yang berhubungan dengan masalah yang sedang diteliti. Adapun metode penelitian yang dimaksud dapat diuraikan sebagai berikut:

\section{Penelitian Kepustakaan (Library Research)}


Penelitian ini untuk mendapatkan data yang bersifat teoritis, mengenai hal-hal yang berkaitan dengan pokok pembahasan, dan dilakukan dengan cara membaca berbagai literaturliteratur dan sumber pustaka lainnya, yang berkaitan dengan penelitian.

\section{Penelitian Lapangan (Field Research)}

Penelitian ini dilakukan dengan cara kunjungan langsung objek penelitian. Adapun dengan teknik pengumpulan data sebagai berikut:

1. Dokumentasi yaitu pengumpulan data yang dilakukan dengan mencatat dokumen dan arsip yang ada pada objek penelitian yang ada hubungannya dengan permasalahan yang ingin diteliti.

2. Quisioner adalah pengumpulan data yang dilakukan dengan cara menyebarkan daftar pertanyaan yang sudah tersedia alternative jawaban yang berhubungan dengan penelitian.

\section{Sumber Data} yaitu:

Data dan Informasi yang diperlukan dalam penelitian ini berdasarkan dari 2 sumber

a. Data primer yaitu data yang diperoleh secara langsung dengan cara observasi, wawancara dan Quisioner.

b. Data sekunder yaitu data yang diperoleh dari studi kepustakaan dan dokumentasi dengan cara berhubungan dengan permasalahan dalam penelitian ini.

\section{Metode Penelitian}

1. Populasi adalah wilayah generelisasi yang terdiri atas obyek atau subyek yang mempunyai kualitas dan karakteristik tertentu yang ditetapkan oleh peneliti untuk dipelajari dan kemudian ditarik kesimpulannya.

2. Sampel adalah bagian dari jumlah dan karakteristik yang dimiliki oleh populasi tersebut. Yang dimaksud dengan sampel adalah merupakan bagian dari populasi.

\section{Operasional Variabel dan Pengukuran Variabel}

Operasional variabel menjelaskan variabel-variabel sesuai dengan fungsi atau kedudukan sebagai variabel independent (X) dan variabel dependent (Y). Dalam penelitian ini yang merupakan variabel independent (X) adalah self assessment system. Indikator dari setiap variabel di atas dijadikan dasar untuk menyusun daftar pertanyaan yang diberikan kepada responden. Data yang terkumpul melalui daftar pertanyaan merupakan data kualitatif kemudian selanjutnya diubah menjadi data kuantitatif dengan cara pemberian nilai pada masing-masing jawaban, terdapat 5 skala tingkatan nilai yaitu :
a. Sangat Taat (ST) score 5
b. Taat (T) score 4
c. Cukup Taat (CT) score 3
d. Tidak Taat (TT) score 2
e. Sangat Tidak Taat (STT) score 1

\section{Analisis Deskriptif}

Analisis ini dilakukan dengan cara mendeskripsikan tanggapan masing-masing jawaban responden terhadap indikator dari variabel yang diteliti. 


\section{HASIL DAN PEMBAHASAN}

\section{Data Penerimaan PPh dan jumlah wajib pajak pada KPP Natar}

Dari data penerimaan PPh (2005-2009) yang diambil dari KPP Natar menunjukkan adanya kenaikan dari jumlah wajib pajak terdaftar setiap tahunnya dan peningkatan jumlah penerimaan $\mathrm{PPh}$,berikut data yang disajikan

Tabel . Jumlah Wajib Pajak dan Data Penerimaan PPh pada KPP Natar

\begin{tabular}{|c|c|c|}
\hline Tahun & Jumlah Wajib Pajak & Penerimaan PPh \\
\hline 2005 & 128 & Rp. 6.823 .585 .333 \\
\hline 2006 & 136 & Rp. 8.571 .735 .732 \\
\hline 2007 & 152 & Rp. 10.990 .831 .189 \\
\hline 2008 & 190 & Rp. 11.766 .575 .557 \\
\hline 2009 & 200 & Rp. 15.317 .933 .232 \\
\hline
\end{tabular}

Sumber: KPP Pratama Natar

\section{Pembahasan}

Tanggapan Wajib Pajak tentang Pengaruh Self Assessment System Terhadap Tingkat Kepatuhan Wajib Pajak pada KPP Pratama Natar

Untuk dapat mengetahui pengaruh Self Assessment System, tidak cukup hanya melihat data laporan penerimaan PPh pada KPP Natar saja, untuk itu penulis juga menguji tanggapan Self Assessment System menurut wajib pajak karena penerapan sistem ini menuntut aktif wajib pajak untuk menghitung, memperhitungkan, membayar, dan melaporkan pajak yang terutang sehingga wajib pajak berperan penting juga dalam pengaruh Self Assessment System terhadap tingkat kepatuhan pada KPP Natar. Maka dibuatlah kategorisasi dari hasil perhitungan terhadap masing-masing indikator tersebut ke dalam 5 kriteria.

Kategorisasi ini dibuat dengan menggunakan skala interval Sebagai berikut:

$I=\underline{\text { nilai tertinggi }- \text { nilai terendah }}$

\section{Kategori}

Diasumsikan jika semua responden memilih jawaban berpoint tinggi yaitu Sangat Taat (5 point) dikalikan dengan jumlah responden maka:

nilai tertinggi $=5$ point $\mathrm{x} 20$ responden $=100$ point

Sebaliknya, jika semua responden memilih jawaban berpoint rendah yaitu Sangat Tidak Taat (1 point) dikalikan jumlah responden maka:

Nilai terendah $=1$ point $\mathrm{x} 20$ responden $=20$ point

Sehingga Interval yang didapat untuk masing-masing kategori adalah:

$$
\begin{aligned}
& I=\frac{100-20}{5} \\
& I=16 \text { interval }
\end{aligned}
$$

\section{Analisis Jumlah Wajib Pajak dan Penerimaan PPh pada KPP Natar}

Berikut merupakan data riset yang diperoleh dari KPP Natar berupa data penerimaan PPh serta Wajib Pajak Terdaftar. 
Tabel . Persentase Jumlah Peningkatan Wajib Pajak dan Penerimaan PPh pada KPP Natar

\begin{tabular}{|c|l|l|l|l|l|l|}
\hline Tahun & Penerimaan PPh & $\%$ & Keterangan & Wajib Pajak & \% & Keterangan \\
\hline 2005 & Rp. 6.823 .585 .333 & - & - & 128 & - & - \\
\hline 2006 & Rp. 8.571 .735 .732 & $26 \%$ & Kenaikan & 136 & $6 \%$ & Kenaikan \\
\hline 2007 & Rp. 10.990 .831 .189 & $28 \%$ & Kenaikan & 152 & $12 \%$ & Kenaikan \\
\hline 2008 & Rp. 11.766 .575 .557 & $7 \%$ & Kenaikan & 190 & $25 \%$ & Kenaikan \\
\hline 2009 & Rp. 15.317 .933 .232 & $30 \%$ & Kenaikan & 200 & $5 \%$ & Kenaikan \\
\hline
\end{tabular}

Sumber : KPP Pratama Natar

Dari tabel diatas pada tahun 2005 sampai dengan tahun 2009 penerimaan $\mathrm{PPh}$ cenderung meningkat. Pada tahun 2006 terjadi peningkatan sebesar 26\%, pada tahun 2007 yaitu $28 \%$ dan pada tahun 2008 sebesar $7 \%$. pada tahun 2009 yang mencapai $30 \%$.

\section{Tanggapan Wajib Pajak Terhadap Pengaruh Self Assessment System Terhadap Penerimaan PPh Pada KPP Natar.}

Tanggapan responden terhadap beberapa pertanyaan dibagi dalam beberapa kategori atau tingkatan dimana kategori yaitu sangat taat, taat, cukup taat, tidak taat dan sangat tidak taat. Tanggapan responden mengenai pengaruh self assessment system untuk 10 pernyataan hasil dari pernyataan yang responden tanggapi taat berjumlah 1, sedangkan 9 pertanyaan ditanggapi cukup taat. Untuk masing-masing indicator, indicator menghitung dikategorikan cukup taat, memperhitungkan cukup taat, indicator lain yaitu menyatorkan cukup taat dan melaporkan cukup taat. Bila dirata-ratakan tanggapan responden mengenai pengaruh self assessment system terhadap tingkat kepatuhan berada pada tingkat cukup taat. Ini dapat diartikan bahwa tanggapan responden mengenai self assessment system cukup baik.

Untuk itu hubungan mengenai pengaruh self assessment system terhadap tingkat kepatuhan pada KPP Pratama Natar, meskipun data dari riset yang dilakukan pada KPP Pratama Natar cukup baik mengalami peningkatan jumlah wajib pajak serta pertumbuhan wajib pajak terdaftar yang selalu meningkat $7 \%$ pertahun.

\section{KESIMPULAN DAN SARAN}

\section{Kesimpulan}

Dari hasil kedua analisis diatas diperoleh kesimpulan sebagai berikut:

Jumlah Wajib Pajak pada KPP Pratama Natar menunjukkan peningkatan tiap tahunnya yang diikuti pertumbuhan tingkat kepatuhan wajib pajak, hal ini menunjukkan adanya hubungan antara Self Assessment System terhadap tingkat kepatuhan wajib pajak.

Penerapan Self Assessment System dalam pertumbuhan jumlah wajib pajak pada KPP Natar menunjukkan sistem ini berkarakteristik efisien dan sederhana karena mempermudah wajib pajak dalam hal menghitung, memperhitungkan, membayar, dan melaporkan sendiri pajak yang terutang, karena karakteristik efisien dan sederhana yang dimiliki sistem ini,

\section{Saran}

Setelah melakukan penelitian dan menganalisis data penelitian serta menyimpulkan data-data yang diperoleh, maka penulis mengajukan beberapa saran yaitu: 
1. Bagi para peneliti lain yang ingin melakukan penelitian sejenis, hendaknya melakukan tinjauan penelitian terhadap faktor lain seperti, tingkat kepatuhan wajib pajak badan dalam ketetapan menyampaikan SPT nya kepada KPP karena tingkat kepatuhan juga bisa diukur dari tepatnya Wajib Pajak badan menyampaikan SPT sesuai dengan ketetapan yang berlaku. Sehingga dapat memberi tambahan bagi khasanah perkembangan ilmu akuntansi.

2. Tingkat kepatuhan di dapat dari berbagai faktor hal tersebut perlu di perhatikan agar Wajib Pajak badan dapat lebih patuh untuk membayar tunggakan pajak yang dikenakan terhadap Wajib Pajak tersebut sehingga apa yang sudah ada saat ini menjadi lebih baik lagi.

Disarankan bagi Direktorat Jendral Pajak dan kantor Pelayanan Pajak hendaknya membantu dalam menginformasi hal-hal yang berkaitan dengan pajak sehingga Wajib Pajak mengetahui informasi tersebut secara cepat, tepat, dan efisien. Sehingga semua Wajib Pajak yang terdaftar bisa tepat waktu menyampaikan SPTnya kepada kantor pelayanan pajak setempat dan yang belum terdaftar sebagai Wajib Pajak bisa secepatnya untuk mendaftar.

\section{DAFTAR PUSTAKA}

Bohari, S.H., MS., 1999. Pengantar Hukum Pajak. Penerbit PT. Raja Gravindo Persada : Jakarta

Tunggal, MBA., Ak 1995. Pelaksanaan Pajak Penghasilan Perseorangan. Penerbit Rineka Cipta

Brotodihardjo, R. Santoso. (2003). Pengantar Ilmu Hukum Pajak. Bandung: Refika Aditama.

Djafar , Dr. Muhammad Saidi, S.H., M.H. (2007). Pembaharuan Hukum Pajak. Jakarta: PT RajaGrafindo Persada.

Mardiasmo, Dr., MBA., Ak. (2007). Perpajakan Edisi Revisi Tahun 2006. Yogyakarta: Adi Yogyakarta.

Saudi, Earli. (2005). Hukum Pajak. Jakarta: Salemba Empat.

Soemitro, H. Rochmat. (2004). Asas dan dasar perpajakan 1. Bandung: Refika Aditama.

Suandy, Erly. (2006). Perpajakan : pembahasan PPh pasal 21 sesuai PTKP 2006. Jakarta: Salemba Empat.

Undang-undang No. 28 Tahun 2007 Mengenai Ketentuan Umum Perpajakan.

Undang-Undang No. 36 Tahun 2008 Tentang Perubahan Keempat Atas Undang-undang No. 7 Tahun 1983 Tentang Pajak Penghasilan.

Waluyo, Drs., M.sc., MM., Akt., dkk. (2005). Perpajakan Indonesia. Jakarta: Salemba Empat.

http://organisasi.org/ilmu pengetahuan/perpajakan 